\title{
Milling Performance of CFRP Composite and Atomised Vegetable Oil as a Function of Fiber Orientation
}

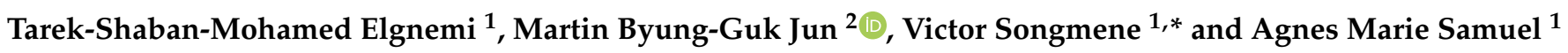 \\ 1 Department of Mechanical Engineering, École de Technologie Supérieure (ÉTS), \\ Montreal, QC H3C 1K3, Canada; tarek-shaban-mohamed.elgnemi.1@ens.etsmtl.ca (T.-S.-M.E.); \\ agnesmsamuel@gmail.com (A.M.S.) \\ 2 Department of Mechanical Engineering, Purdue University, West Lafayette, IN 47907, USA; \\ mbgjun@purdue.edu \\ * Correspondence: Victor.Songmene@etsmtl.ca
}

check for updates

Citation: Elgnemi, T.-S.-M.; Jun, M.B.-G.; Songmene, V.; Samuel, A.M. Milling Performance of CFRP Composite and Atomised Vegetable Oil as a Function of Fiber Orientation. Materials 2021, 14, 2062. https:// doi.org/10.3390/ma14082062

Academic Editor: Jun Liu

Received: 30 March 2021

Accepted: 17 April 2021

Published: 20 April 2021

Publisher's Note: MDPI stays neutral with regard to jurisdictional claims in published maps and institutional affiliations.

Copyright: (c) 2021 by the authors. Licensee MDPI, Basel, Switzerland. This article is an open access article distributed under the terms and conditions of the Creative Commons Attribution (CC BY) license (https:/ / creativecommons.org/licenses/by/ $4.0 /)$.

\begin{abstract}
Carbon fiber reinforced polymers (CFRPs) have found diverse applications in the automotive, space engineering, sporting goods, medical and military sectors. CFRP parts require limited machining such as detouring, milling and drilling to produce the shapes used, or for assembly purposes. Problems encountered while machining CFRP include poor tool performance, dust emission, poor part edge quality and delamination. The use of oil-based metalworking fluid could help improve the machining performance for this composite, but the resulting humidity would deteriorate the structural integrity of the parts. In this work the performance of an oil-in-water emulsion, obtained using ultrasonic atomization but no surfactant, is examined during the milling of CFRP in terms of fiber orientation and milling feed rate. The performance of wet milling is compared with that of a dry milling process. The tool displacement-fiber orientation angles (TFOA) tested are $0^{\circ}, 30^{\circ}, 45^{\circ}, 60^{\circ}$, and $90^{\circ}$. The output responses analyzed were cutting force, delamination, and tool wear. Using atomized vegetable oil helps in significantly reducing the cutting force, tool wear, and fiber delamination as compared to the dry milling condition. The machining performance was also strongly influenced by fiber orientation. The interactions between the fiber orientation, the machining parameters and the tested vegetable oil-based fluid could help in selecting appropriate cutting parameters and thus improve the machined part quality and productivity.
\end{abstract}

Keywords: CFRP; dry/vegetable oil; cutting force; delamination; tool edge rounding

\section{Introduction}

Carbon fiber reinforced polymers (CFRPs) find many industrial applications (automotive, aerospace, sporting goods, medical and military) because of their attractive specific strength, specific modulus, damage tolerance characteristics [1,2], and resistance to fatigue and corrosion [3,4]. Despite their promising outlook, the machinability of CFRPs has often been poor because of excessive tool wear [5,6], machining-induced delamination [7,8], fiber fragmentation, pull-out, and spalling $[9,10]$. In particular, abrasive carbon fibers rapidly wear out the tool, changing its geometry and damaging the subsurface of the work piece [11]. Alternative machining strategies must be found to shape CFRP parts with acceptable tool life, good part quality/accuracy and less surface and subsurface damages. Considerable improvement has been accomplished in terms of comprehension of machinability during milling of isotropic materials, such as metals [12,13]. In spite of this research, outcomes cannot be immediately applied to the milling of CFRP laminates due to the current inhomogeneity and anisotropy of these materials [14]. Unlike minerals that are outwardly homogeneous, where machining is a matter of plastic deformation and shear, the machining of CFRPs is related to plowing, cutting, and cracking $[15,16]$.

Structural CFRP parts are shaped using a milling process and then drilled in order to assemble them (riveting, bolting) with other components [17,18]. Most researchers 
recognize the difficulties in applying knowledge obtained during machining of metals or other types of material to CFRPs because of inhomogeneity, anisotropy [12,13], and damages occurring during cutting [14]. In fact, during machining of CFRPs, plowing, cutting, and cracking occur [16,19], whereas the machining of metals takes place by shearing and plastic deformation [20]. The machining of CFRPs is also influenced by the machining parameters and conditions which affect the cutting force/temperature and, therefore, the tool wear and part quality [21,22]. To overcome these difficulties, several studies have investigated the machining of CFRPs in order to propose optimal machining parameters and conditions such as cutting speed $[23,24]$, feed rate $[25,26]$, and depth of cut $[27,28]$. One of the most interesting results from these studies was that machinability and tool wear processes strongly depend on fiber-orientation corresponding to the cutting direction. It has also been recognized that the subsurface damage and high surface roughness associated with machining often results in poor surface quality that is unacceptable for design $[29,30]$. The effects of material and machining conditions on tool wear have been investigated in the drilling of CFRP [31,32]. The results show an improvement in the drilled hole quality. These works demonstrate, among other things, the influence of cutting direction relative to fiber orientation on the machinability of CFRPs, particularly on tool wear and part quality. Part subsurface damage and high surface roughness are unacceptable in the use of these composites [25].

Cutting fluids are usually used for improving tool life, surface finish and lowering cutting forces when machining metallic materials. They also flush chips away from the cutting zone and reduce dust generated in the working environment, thus improving occupational safety. In the case of CFRPs, this is inadvisable because of the negative impact on the structural integrity of the composite [20].

An innovative method (fully wet or semi-wet) that can cool down the tool [33] or lubricate the cutting process without being absorbed by the workpiece material is feasible for the machining of CFRPs [34,35]. This is the case for cryogenic machining, which was found to improve tool life and part surface integrity during drilling of CFRPs [36,37]. In recent years, some authors $[38,39]$ have studied tool wear in the milling and edgetrimming of CFRPs using chilled air and dry cutting conditions. They observed that using chilled air improved the tool life of uncoated carbide cutting tools compared to dry machining, provided the feed rate was selected with care, this being an influential process parameter.

Moreover, vegetable-based oils have also been proposed as a viable alternative $[40,41]$ as they are environmentally friendly and show highly suitable lubricity and other characteristics. These vegetable oils include canola, soybean, and rapeseed oil. Research on the development and formulation of vegetable oil-based metal working fluids (MWFs) can be found in [41], while their performance is reported in [42,43]. These vegetable-based oils appear definitively as a good alternative to mineral-based cutting oils [44,45]. Ultrasonic vibration can be used to emulsify vegetable oil in water [46,47]. However, the feasibility of using such fluid as an MWF for machining has not been investigated, with the exception of the authors' previous works $[48,49]$. The performance of such a cutting fluid on CFRPs was studied in [48] and it was reported that this fluid effectively reduced tool wear, cutting forces, surface roughness, burr occurrence, and dust and airborne concentrations in the machining environment. However, the study did not address the effect of fiber orientation.

Therefore, this work is mainly motivated by two objectives: (i) the need to study the performance of ultrasonic atomized vegetable oil in water as a sustainable alternative to conventional cutting oils and coolants; and (ii) to study the impact of fiber orientation on the tool degradation mode (edge rounding); the quality of the machined surface, delamination percentage and fiber length are also considered in regard to the latter.

The article is organized as follow: Section 2 describes the experimental setup, workpiece, cutting tool and the design of experiments. The results (cutting forces, friction angle, tool wear, and delamination) are presented and discussed in Section 3. The concluding remarks are given in Section 4. 


\section{Methodology}

\subsection{Machining Process Setup}

The system of atomization-based cutting fluid spray is similar to the one given by Elgnemi et al. in [48]. The atomized canola vegetable oil and water is directly applied to the cutting zone to lubricate the chip and tool interface. The average droplet size of the canola oil is around $2.1 \mu \mathrm{m}$ [49]. More details are available in [50,51]. Slot milling tests are carried out under cutting conditions as shown in Figure 1. The machine-tool used in this work was ALIO vertical milling machine (supplied by Alio Industries) which has a spindle speed range of 10,000 to $80,000 \mathrm{rpm}$. The workpiece was clamped on the table dynamometer fixed on the machining center. Cutting forces were measured using a Kistler MiniDyn 9256C1 dynamometer as shown in Figure 1. A data acquisition (DAQ) board from National Instruments (NI-P/N-USB-6251 BNC) was used to acquire the measured forces from the dynamometer. The CutPro software program (developed by Prof Y. Altintas' team, University of British Colombia, Vancouver, Canada) was used to receive data from the DAQ board during the machining operation. A sampling rate of $100 \mathrm{kHz}$ was used to process the measured force data. For comparison purposes, the experiments were carried out in both dry conditions and wet conditions using canola vegetable oil.

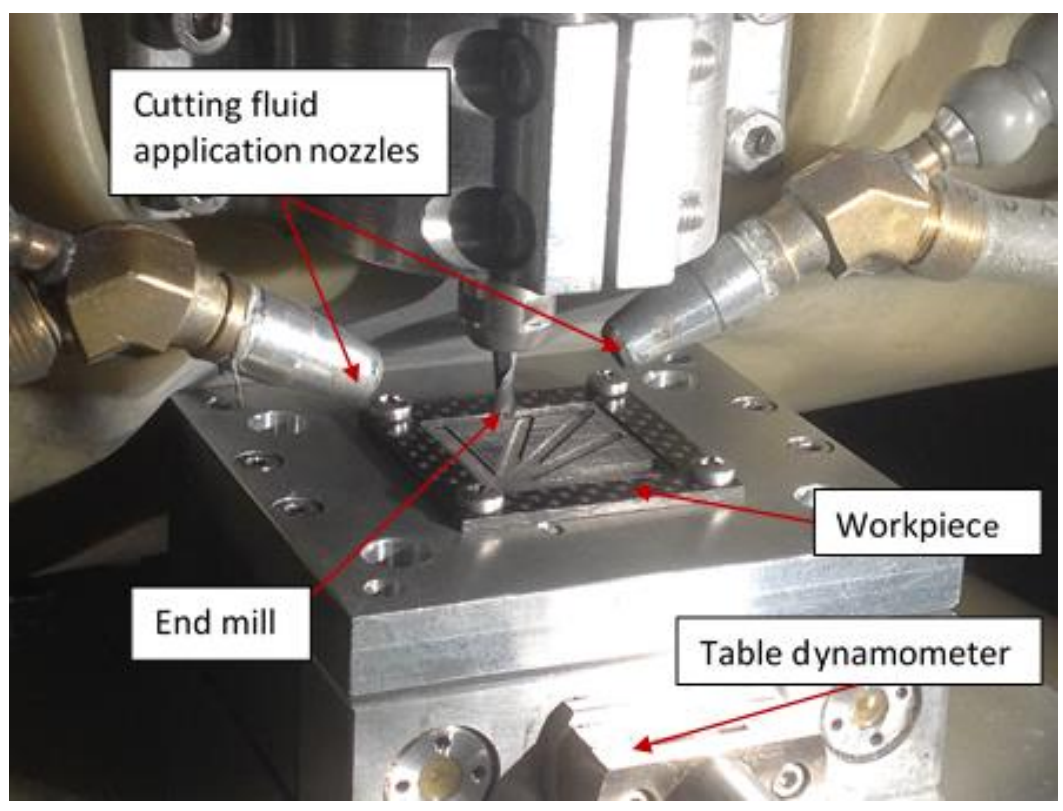

Figure 1. Experimental set-up consisting of a workpiece mounted on table dynamometer, end mill cutting tool and cutting fluid application nozzles.

In the latter case, distilled water was added into the atomizer to dilute the fluid at 5 vol. \%.

\subsection{Workpiece Materials and Cutting Tool}

Multi-layer CFRP sheets $1.56 \mathrm{~mm}$ thick were used as workpiece material in this study. Each cut was done at a unidirectional fibers orientation with a depth of cut of $0.3 \mathrm{~mm}$. Each composite sheet consisted of four unidirectional tapes (54 vol.\% fibers per tape) laid up in $0^{\circ}$ and $90^{\circ}$ orientations. The combined Young's modulus of 104 fibers (in the sheets) was $225 \mathrm{GPa}$ ( $65 \mathrm{GPa}$ per tape). The workpiece materials were cut into small sheets of 38 $\mathrm{mm}$ length $\times 38 \mathrm{~mm}$ width. The tests were performed on unidirectional laminates and the cutting directions were set so that the fiber orientation angle with respect to the cutting direction was $0^{\circ}, 30^{\circ}, 45^{\circ}, 60^{\circ}$ and 90 .

The tool geometry information for the uncoated tungsten carbide (WC-Co) 2-flutes end-mills (MSC Industrial Supply, Elkhart, IL, USA) used in the experiment are summarized in Table 1. 
Table 1. Description of the geometry of end mill used.

\begin{tabular}{cccccc}
\hline $\begin{array}{c}\text { Cutter } \\
\text { Diameter }\end{array}$ & Flute Length & $\begin{array}{c}\text { Shank } \\
\text { Diameter }\end{array}$ & $\begin{array}{c}\text { Overall } \\
\text { Length }\end{array}$ & Rake Angle & Helix Angle \\
\cline { 1 - 4 } $0.125 \mathrm{in}$ & $0.250 \mathrm{in}$ & $1 / 8 \mathrm{in}$ & $1.50 \mathrm{in}$ & $7^{\circ}$ & $30^{\circ}$ \\
\cline { 1 - 4 } $3.175 \mathrm{~mm}$ & $6.35 \mathrm{~mm}$ & $3.175 \mathrm{~mm}$ & $38.1 \mathrm{~mm}$ & \\
\hline
\end{tabular}

\subsection{Measurement of Cutting Forces and Friction Angle}

The forces $F c, F t$ and $R$ are the main cutting force, thrust force and resultant cutting force, respectively. They are calculated from the measured normal force $F x$ and the feed force $F y$ in the $x$ and $y$ directions. The magnitude of $F z$ was negligible compared to $F x$ and $F y$. The relationships between these forces are: [52]

$$
\begin{gathered}
F c=-F x \sin \varnothing+F y \cos \varnothing \\
F t=F x \cos \varnothing+F y \sin \varnothing \\
R=\sqrt{F c^{2}+F t^{2}}
\end{gathered}
$$

Since the un-deformed thickness of the chip $t$ is almost the same as the depth of cut used, (given the brittle nature of the CFRP $[53,54]$ ), the shear angle $\varnothing$ can be estimated through the tool rake angle $(\alpha)$ by:

$$
\varnothing \approx \tan ^{-1}\left(\frac{\cos \alpha}{1-\sin \alpha}\right)
$$

and the friction angle $(\beta)$ by [52]:

$$
\tan (\beta)=\frac{F t+F c \tan \alpha}{F c-F t \tan \alpha}
$$

\subsection{Edge Rounding Measurement}

The effective cutting-edge radius affects the machining performance (forces, power requirements) and the part surface finish. In this study, changes in cutting edge evolution were taken into consideration. A 3D optical microscope (Olympus BXFM) was employed for monitoring the change in the tool point or nose radius. Microscope images of a sharp cutting-edge are shown in Figure 2a and microscope image of the same cutting edge after milling three slots (total cutting distance of $66 \mathrm{~mm}$ ) is shown in Figure $2 \mathrm{~b}$. The tools were cleaned in acetone in an ultrasonic bath at $60^{\circ} \mathrm{C}$ for 30 min (frequency: $1000 \mathrm{kHz}$, power: $60 \mathrm{~W})[55,56]$, and [57]. The radius was estimated using the best-fit radius (highlighted circle) between the flank and the rake face of the worn tool. The tangential intersection with the flank face and the tangential intersection with rake face represent a series of radiuses measured from the worn cutting-edge profile between flank and rake face, as shown in Figure $2 \mathrm{~b}$. The radius of the circle that is confined between the two lines is considered as the resulting tool wear. 


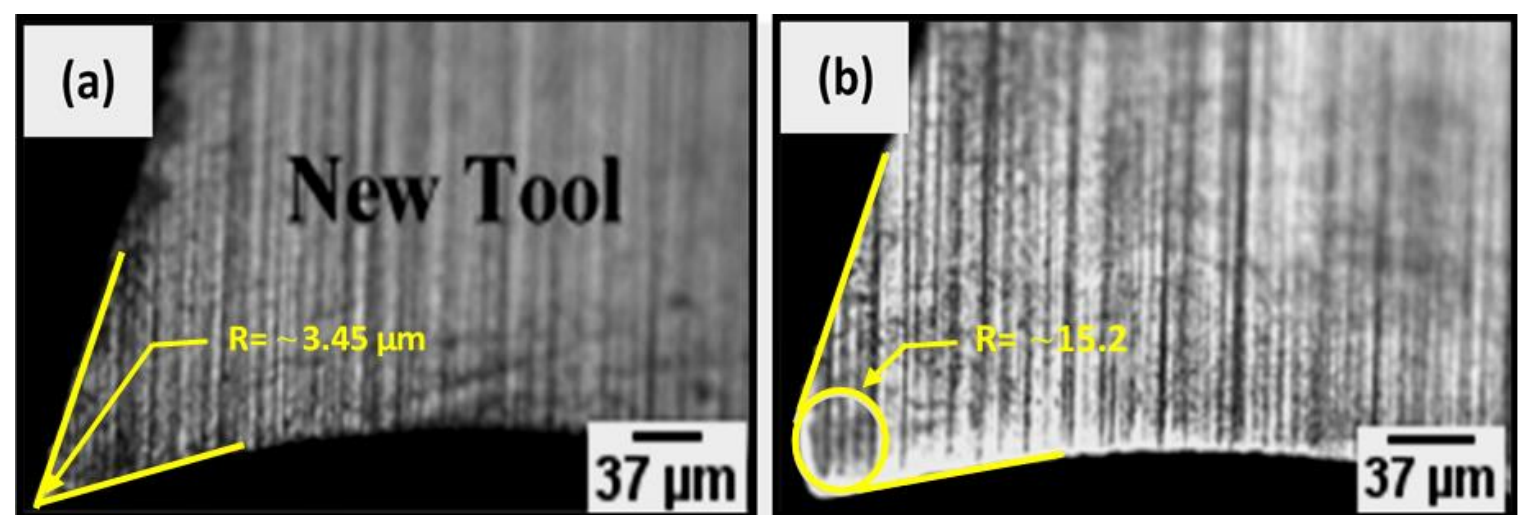

Figure 2. Procedure for measuring the tool nose radius. (a) New tool, (b) worn tool for a cutting distance of $66 \mathrm{~mm}$ with $0^{\circ}$ TFOA at a feed rate of $3 \mu \mathrm{m} /$ tooth and 20,000 rpm, in the dry condition.

\subsection{Delamination Measurement}

Delamination is a common occurrence when milling CFRPs. This machining-induced damage can be estimated using the delamination percentage $D p$, measured using the maximum damage width $\left(W_{\max }\right)$ and the programmed slot width $(W)$, corresponding to endmill diameter in Equation (6) [58]. $W_{\max }$ was estimated using optical microscope observations. Figure 3 shows a schematic representation of these terms.

$$
D p=100 \frac{W \max -W}{W}
$$

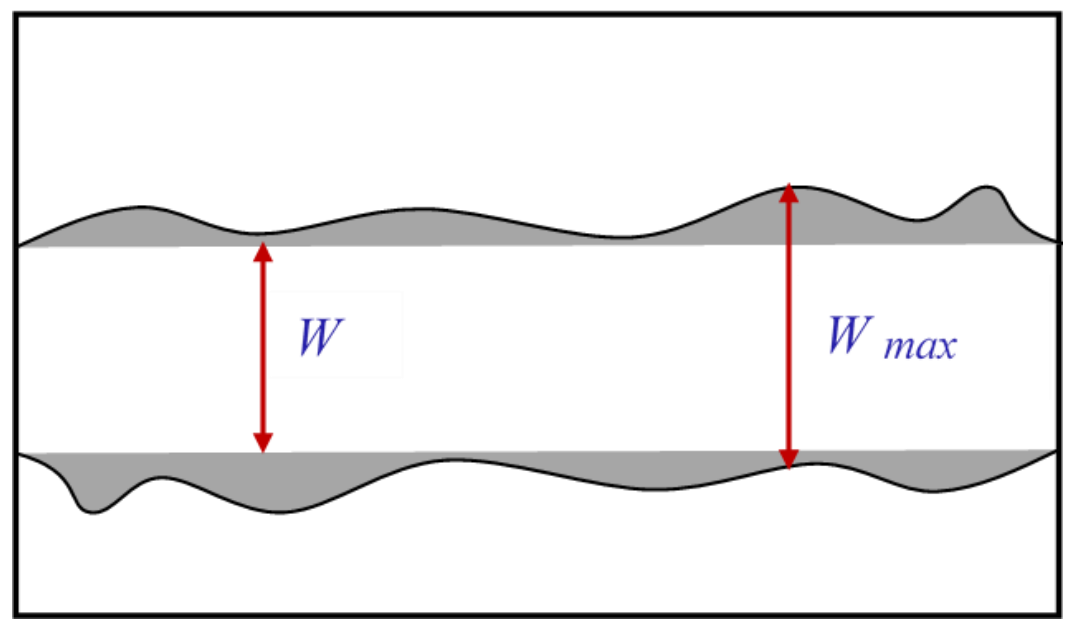

Figure 3. Schematic representation of CFRP damage measurement technique.

\subsection{Chip Formation Characterization Processes}

After machining, chips were collected for each of the cutting directions $\left(0^{\circ}, 30^{\circ}\right.$, $45^{\circ}, 60^{\circ}$, and $90^{\circ}$ ) relative to fiber orientations (TFOA) of CFRP. These chips were then measured and imaged employing a Hitachi S-4800 FESEM. Figure 4 shows the technique for measuring the fiber length as well as examples of chip morphologies observed. In this image, we can distinguish fibers separated from the matrix. Broken short fibers may have been wiped out during the cleaning procedure. The lengths of exposed long fibers were estimated using Image J software. 


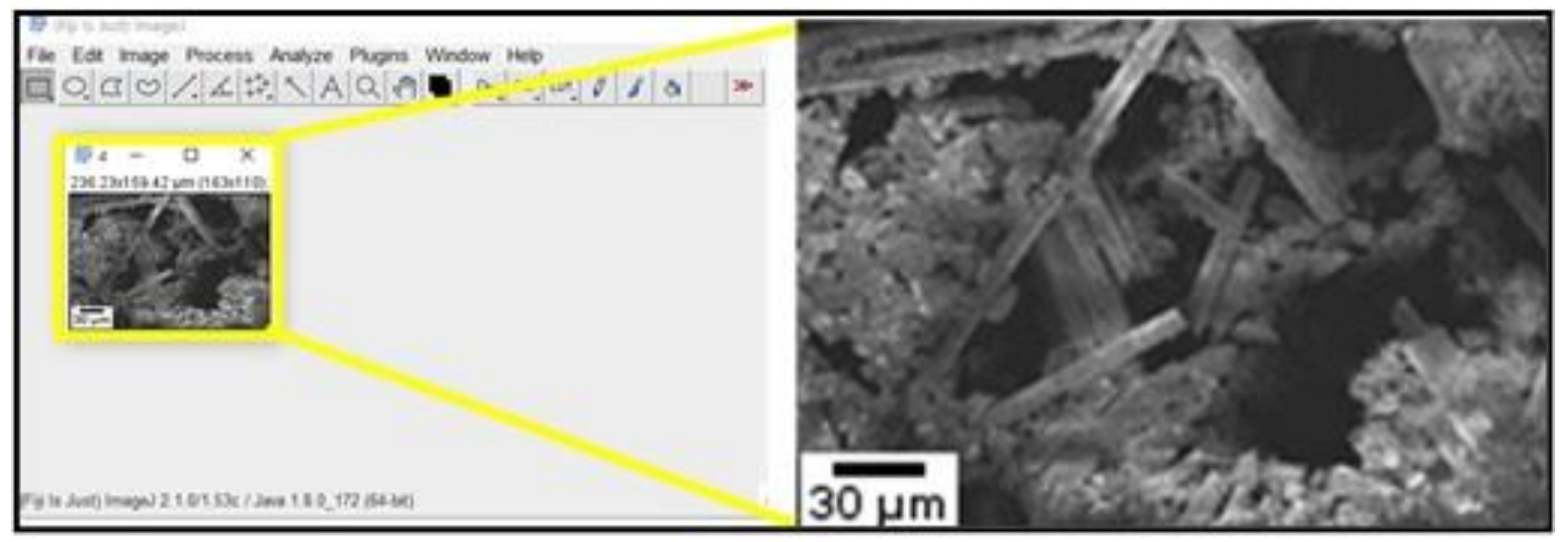

Figure 4. Fiber length measurement technique.

\subsection{Experimental Design}

A factorial design approach was implemented to look into the milling parameters and cooling method effects on the machining of CFRP. The tested factors included: (a) the fiber orientation angle with respect to the cutting direction as shown in Figure 5; (b) the feed rate; and (c) the cooling method. Five fiber orientation angles (TFOA: $0^{\circ}, 30^{\circ}, 45^{\circ}$, $60^{\circ}$, and $90^{\circ}$ ), two feed rates and two cooling methods (dry versus atomized vegetable oil) were selected. In all, twenty experiments were necessary for the full factorial design. Each test was repeated three times. A new tool was used for each test. Table 2 summarizes the controlled factors, their level and the output responses analyzed. The others milling parameters were set as follows:

- Spindle speed: 20,000 rpm

- Tool immersion: $100 \%$

- Axial depth of cut: $0.3 \mathrm{~mm}$

- Length of each slot: $22 \mathrm{~mm}$

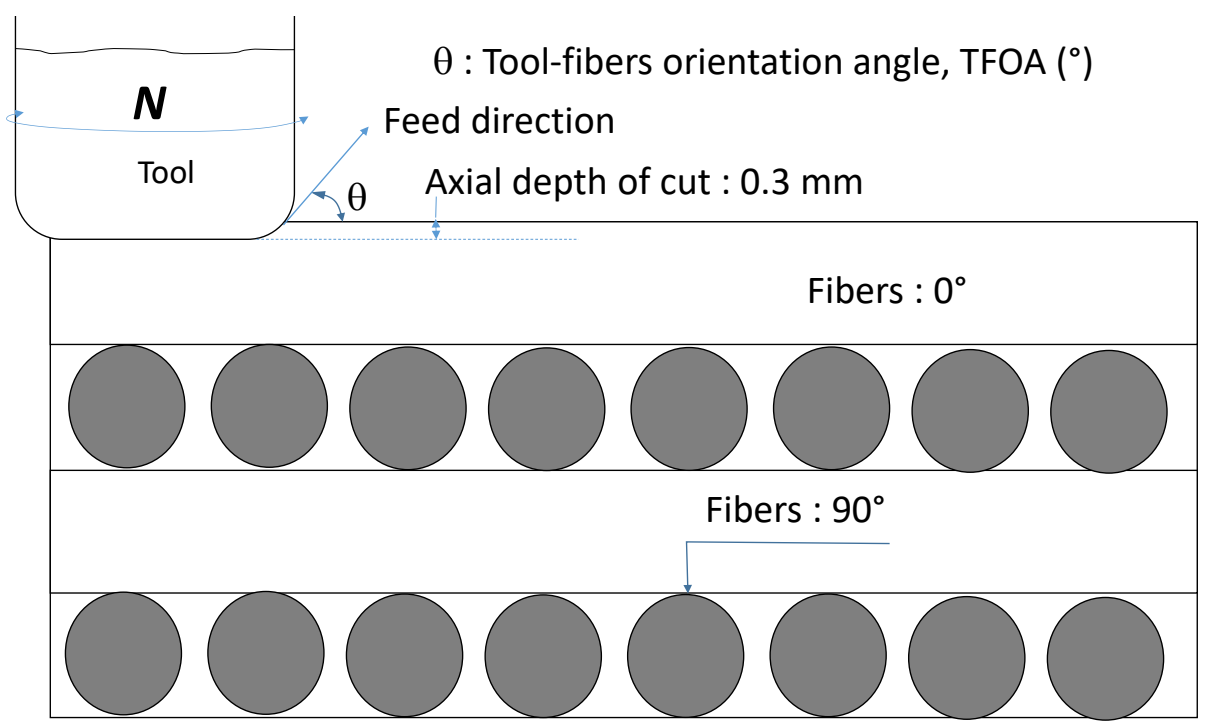

Figure 5. Schematic representation of tool displacement-fibers orientation angle. 
Table 2. Details of milling experiments with and without atomization-based cutting fluid (ACF).

\begin{tabular}{clcl}
\hline Ident. & Control Variables & Levels & \multicolumn{1}{c}{ Response Variables } \\
\hline & & & 1. Cutting forces \\
A & Fiber orientation $\left(\theta^{\circ}\right)$ & $0,30,45,60,90$ & 2. Tool wear \\
B & Feed rate $(\mu \mathrm{m} /$ tooth) & 3,6 & 3. Delamination \\
C & Cutting fluids & Dry-ACF (vegetable oil) & 4. Surface damage \\
& & & 5. Chip formation \\
\hline
\end{tabular}

The depth of cut was chosen so as to be able to make three passes on the same fiber orientation.

\section{Results and Discussion}

\subsection{Cutting Forces}

The influence of feed rate and fiber orientation on the resultant cutting force $(R)$ obtained when using dry and ACF (atomized cutting fluid i.e., vegetable oil) milling conditions are shown in Figure 6. For all tested parameters, a slight increase in $R$ was observed with dry milling of uni-directional or UD-CFRP laminates compared to atomization-based spray machining regardless of TFOA and feed rate. This can be attributed to the lubricating effect due to the ACF resulting in reduced friction at the tool/chip and tool/work piece interfaces when atomized cutting fluid is used. Moreover, in Figure 7 the highest magnitude of $R$ is noted at $90^{\circ}$ fiber orientation, whereas the $R$ value is lowest for $0^{\circ}$ orientation, namely when the cutting direction and fibers are parallel. In such a setting, the main mechanism for chip formation is delamination, and therefore the interaction of fibers with the cutting edge is limited. In the opposite case, when the fibers are perpendicular to the cutting direction (i.e., at $90^{\circ} \mathrm{TFOA}$ ), the tool must cut the fibers that have a higher Young's modulus than the matrix. For the $45^{\circ}$ fiber orientation, the fibers undergo both pulling and shearing [57]. It appears in Figure 6 that the resultant force increases proportionally to the feed rate, as usually expected when machining metals, polymers and composites since the chip thickness and cross section, and therefore the metal removal rates, are increased at a high feed rate [59]. The results presented in Figures 6 and 7 demonstrate that the machining of CFRP is improved with the use of the atomization-based vegetable oil spray as the lubricant.
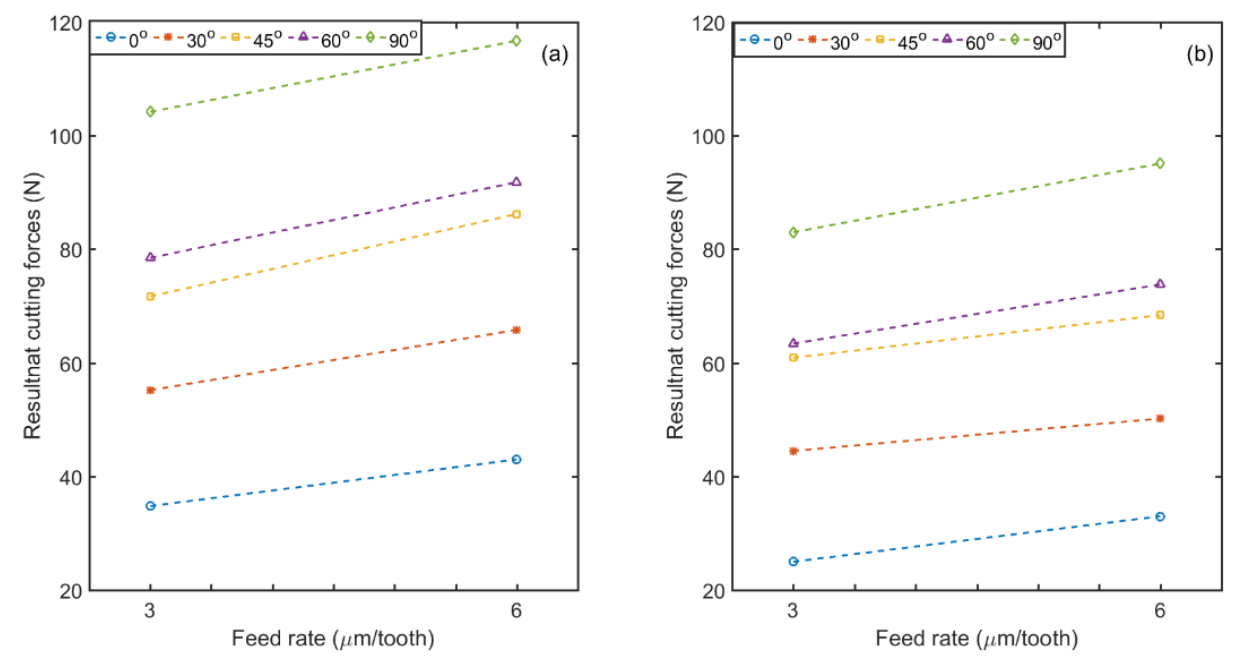

Figure 6. Influence of feed rate and fiber orientation on resultant cutting forces.in the (a) dry, and (b) ACF vegetable oil conditions (at 20,000 rpm speed). 


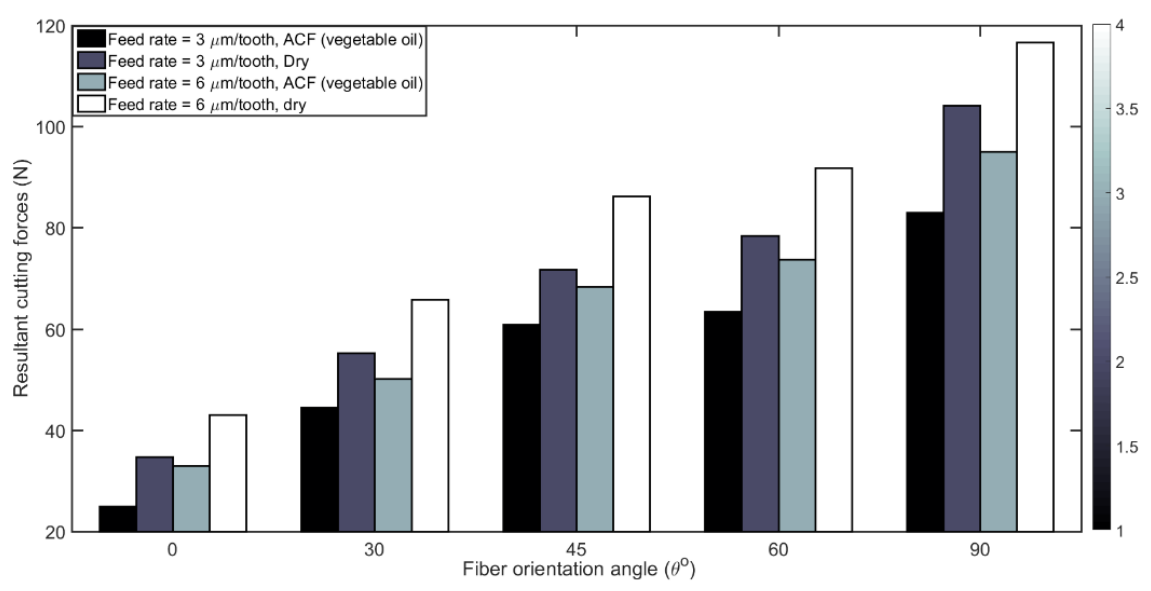

Figure 7. Resultant cutting forces for all fiber orientations using 3 and $6 \mu \mathrm{m} /$ tooth feed rates and different cutting conditions. (Speed: 20,000 rpm).

\subsection{Friction Angle}

The bar diagram in Figure 8 illustrates the friction angle by feed rate and fiber orientation. The friction angle $\beta$ is plotted according to Equation (5). Regardless of the dry or lubricated conditions, it appears that the friction angle decreases as the cutting direction changes from $0^{\circ}$ to $90^{\circ}$ orientation. The reduction in $\beta$ is limited from $0^{\circ}$ to $45^{\circ}$ and high when cutting in fiber orientation between $60^{\circ}$ to $90^{\circ}$. This can be explained by the fact that, for high fiber angles (more than $45^{\circ}$ ), the double fiber removal actions of pulling and shearing lead to reduction in chip-tool contact length and thus reduce the friction. The rupture of fibers strongly depends also on the TFOA as well as the effective rake angle $\alpha$, Equation (5) [60]. Figure 8 also shows that $\beta$ decreases proportionally with an increase in the feed rate (i.e., chip thickness) for each unidirectional CFRP laminate when the cutting conditions are the same. This observation may be ascribed to the reduction in the un-deformed chip thickness which depends on the amount of feed per tooth; as a result the friction angle $\beta$ at the tool face will decrease as the feed per tooth is increased [61]. The other differences in friction angles observed, especially as a function of TFOA, could be attributed to the chip formation process [53]. Finally, the use of ACF lubricant will also reduce the friction angle. Moreover, referring to Equation (5), the theoretical friction angle would decrease with a higher cutting force. The parameters affecting the machining force, as described in the previous sub-section, further corroborates the correlation between the increase in cutting force and the decrease in friction angle.

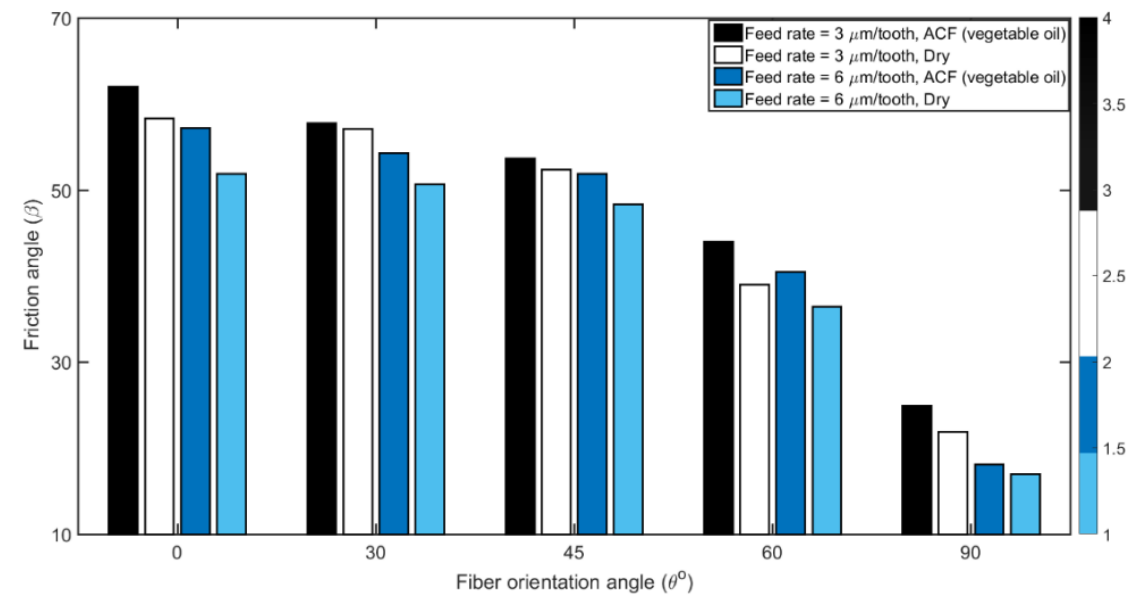

Figure 8. Comparison of measured friction angle as a function of fiber orientation at feed rates with 3 and $6 \mu \mathrm{m} /$ tooth and different cutting conditions (at 20,000 rpm speed). 


\subsection{Tool Wear-Edge Rounding}

The dominant tool wear mode when machining CFRP has already been identified as the blunting of the cutting edge [62,63], also known as edge rounding [64,65]. Figure 9 shows comparative images of the tool after milling three slots (total travel distance of $66 \mathrm{~mm}$ ) under different lubricating conditions and for tested fiber orientation angles. The higher the fiber orientation, the higher the edge rounding observed after milling. Figure 10 presents a comparison of edge rounding in terms of fiber orientation, milling condition and feed rate. It appears from the trends of Figure 9 that, irrespective of fiber orientation angles and feed rate values, the cutting edges develop a large edge radius caused by the abrasion of the tool flank and rake faces by the broken carbon fibers. Figure 10 displays how the measured tool edge rounding radius varies with the feed per tooth and the use (or not) of cutting fluid. From this figure, it is noted that tool wear is much greater when no lubricant was used, due to the increase in friction.

Fiber Orientation Angle $\left(\theta^{\circ}\right)$

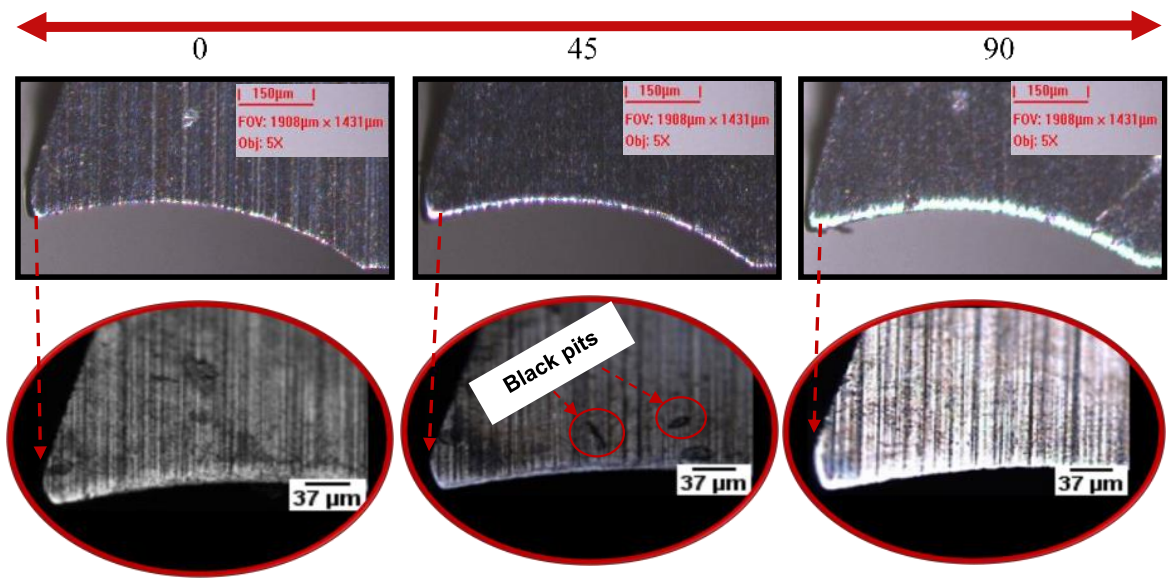

(a)
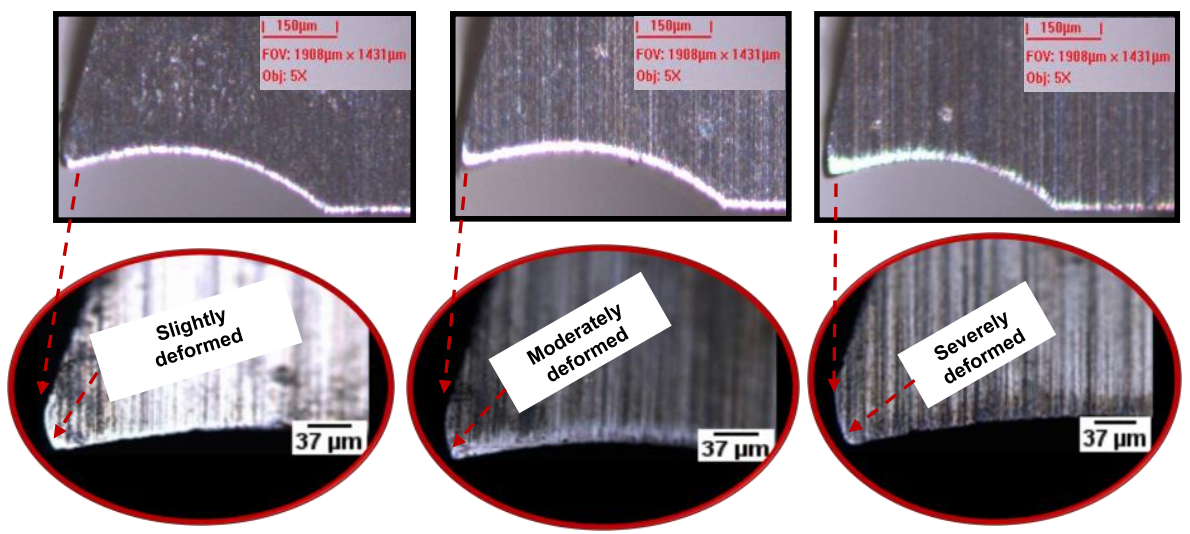

(b)

Figure 9. Progression of wear after milling $66 \mathrm{~mm}$ at $0^{\circ}, 45^{\circ}$, and $90^{\circ}$ fiber oriented at feed rate $3 \mu \mathrm{m} /$ tooth, and 20,000 rpm using (a) atomization-based spray and (b) dry milling. 

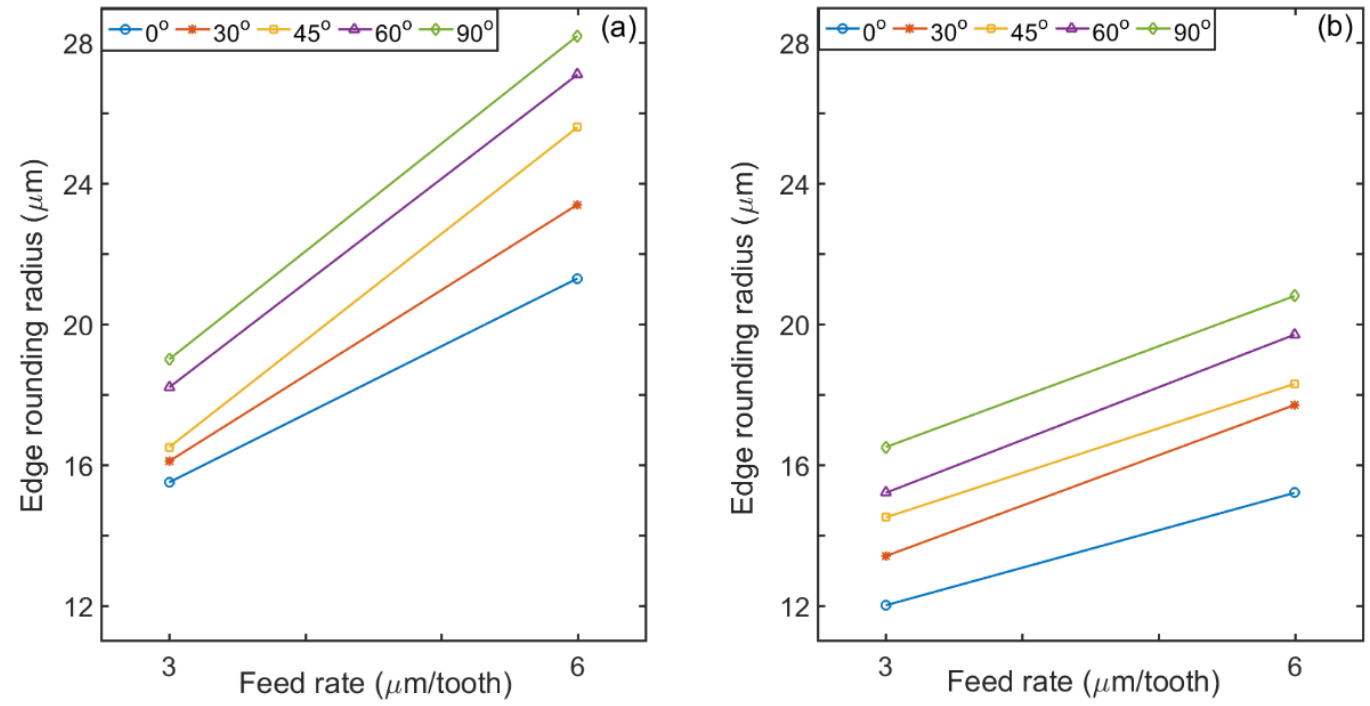

Figure 10. Comparison of measured edge rounding radius progress for all fiber orientations at feed rates 3 and $6 \mu \mathrm{m} /$ tooth and speed of 20,000 rpm for (a) dry and (b) ACF vegetable oil conditions.

In general, the increase in edge rounding radius was high for cutting fibers at $90^{\circ}$ (i.e., perpendicular to the cutting direction) and least for fibers cut at $0^{\circ}$. This may be attributed to shear fracture that occurs during CFRP chip formation when cutting with $90^{\circ}$ as reported by Maegawa et al. [66]. This result also explains the highest cutting force observed at $90^{\circ}$ fiber orientation (Section 3.1) During machining at $45^{\circ}$, the cutting force was not as high as for $90^{\circ}$ (Figures 6 and 7). These results are in keeping with those reported by Wang et al. [25].

The low edge rounding radius observed at $45^{\circ}$ and $0^{\circ}$ may be accounted for in terms of the chip formation. When milling at $45^{\circ}$, the abrasive action of the broken fibers is high. These fibers are broken because of the compression-induced shear perpendicular to the fiber direction [59]. When machining at $0^{\circ}$, fiber delamination occurs because of micro-buckling and only limited fibers can fracture [67].

It is also observed in Figure 10 that the tool deterioration (edge rounding) was reduced during milling for all cutting directions using atomized vegetable oil conditions. It can be observed too, for all lubrication conditions tested, that the tool wear increases when the feed rate and thus the load on the tool is increased.

\subsection{Delamination}

Figure 11 displays the percentage of delamination measured (Equation (6)) as a function of TFOA and feed rate on samples machined under dry and wet conditions. It can be seen that, when milling using the atomized coolant, the percentage of damage on the workpiece is greatly reduced for all the tested conditions. The resulting reduction of temperature in the cutting zone can explain this behavior since it would reduce the thermal degradation of the polymer matrix. This result is in good agreement with the observations of Kumar et al. [59] who found that low temperatures tend to maintain or increase the properties of the CFRP (tensile strength, shear modulus and stiffness) which, in consequence, would produce greater resistance to delamination. 


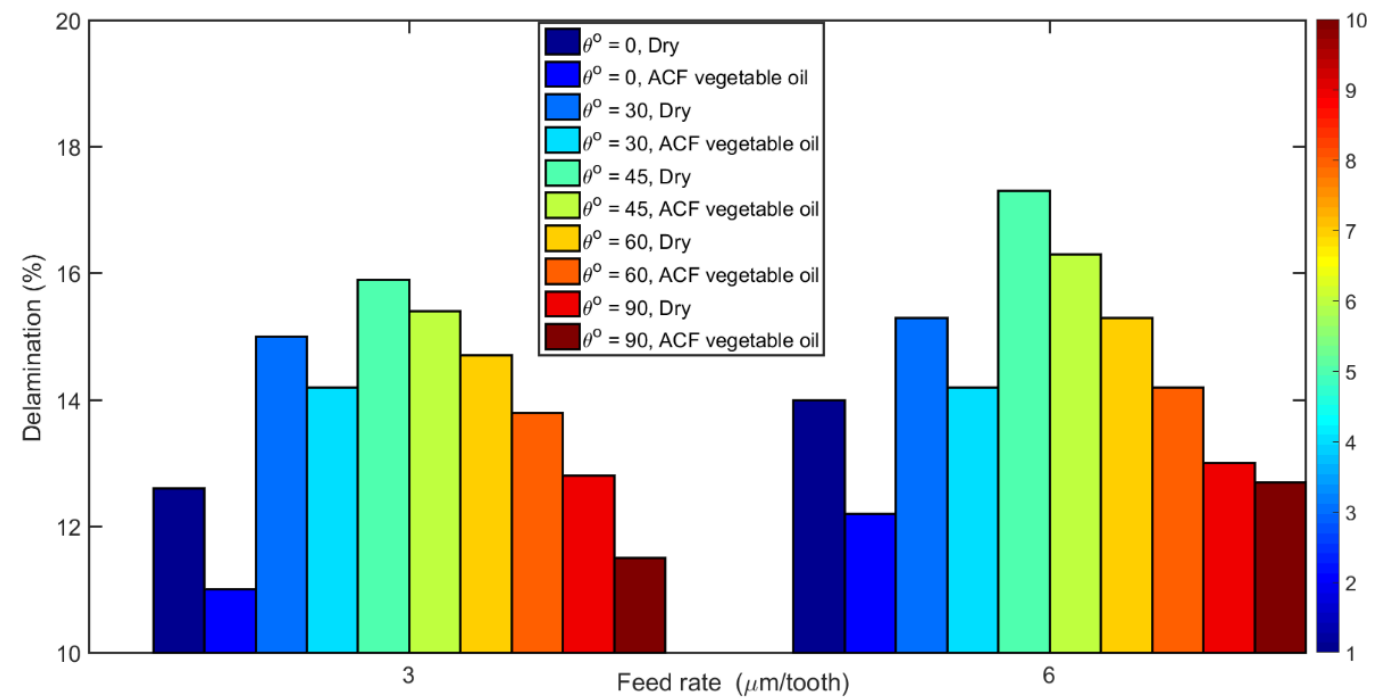

Figure 11. Variation in delamination percentage with fiber orientation angle at feed rates 3 and $6 \mu \mathrm{m} /$ tooth and different cutting fluid conditions (at 20,000 rpm speed).

The maximum damage occurred when cutting dry at $45^{\circ}$ fiber orientation using a high feed rate (Figure 11). The dominant chip formation mechanisms, i.e., fiber bending and shearing, for this configuration can explain this maximum delamination. Also, the more the feed rate is high, the higher the delamination that takes place, which can be attributed to the increase in cutting forces and thus on shear stress when the feed rate is increased.

\subsection{Chip Formation}

In general, the chip formation observed during milling of CRPFs is dominated by delamination and breakage. The reinforcing fibers break into dust particles of different shapes and this tendency varies depending on the direction of cutting relative to the fiber orientation. Figure 12 shows SEM images of fibers and chips obtained, in relation to the feed rate and TFOA. Measurements of broken fibers were taken from these images to ascertain their lengths in order to correlate them with the machining conditions (see Figure 12).

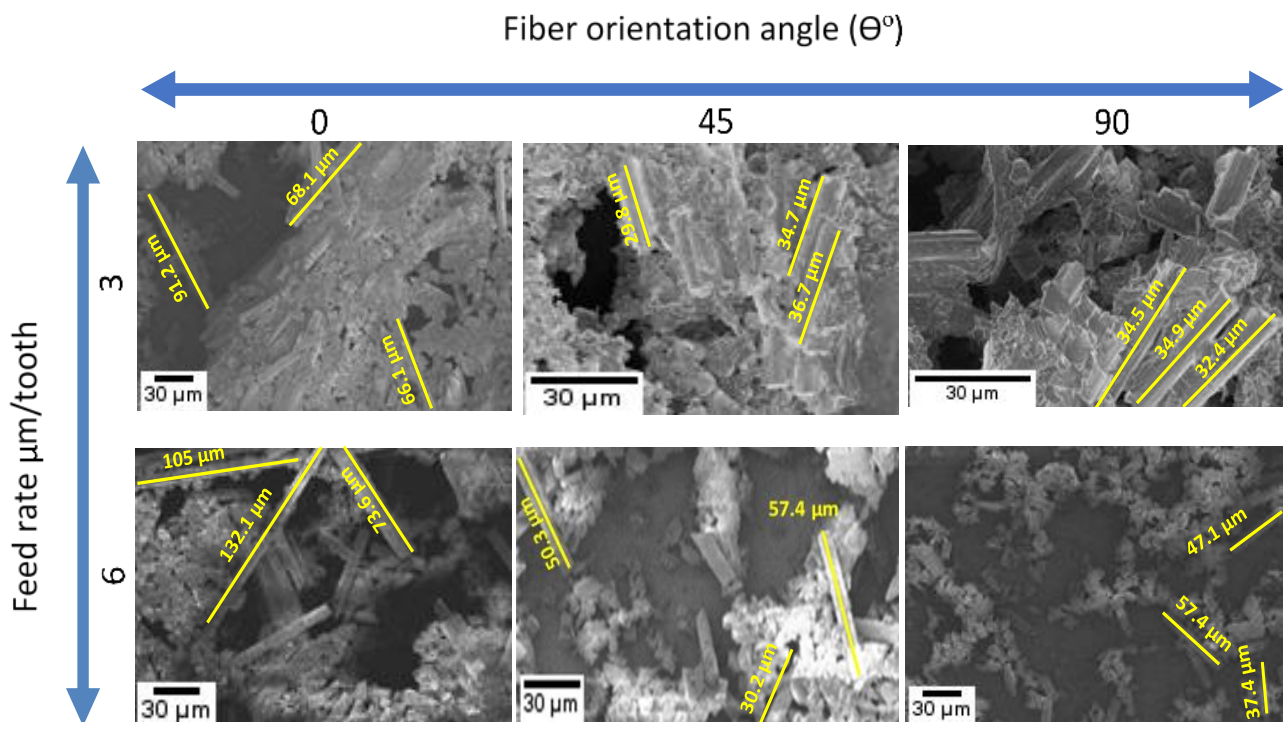

Figure 12. SEM images used for fiber length measurements for fiber orientations $\theta^{\circ}=0,45$, and 90 at feed rates 3 and $6 \mu \mathrm{m} /$ tooth and dry milling condition (at 20,000 rpm speed). 
It is clearly noted in Figure 12 that the chips are broken into fiber segments of irregular lengths. Longer broken fibers were obtained at $0^{\circ}$ TFOA while much shorter ones were generated at $45^{\circ}$ and $90^{\circ}$ TFOAs. The chip formation modes at $0^{\circ}$ TFOA (i.e., delamination [16,57]) and at $45^{\circ}$ and $90^{\circ}$ TFOAs (i.e., compression-induced shear fracture perpendicular to fibers and inter-laminar shear fracture along the fiber/matrix interface $[16,68]$ can explain the difference found in the broken fiber lengths. These broken fibers abrade the tool, which explains the high edge radius roundness observed when milling at $0^{\circ}$ orientation (see Figure 10). It was also observed from Figure 13 that fiber length increases proportionally to the feed rate (i.e., chip thickness) for all fiber orientations. For instance, the average fiber length increased, from $75.1 \mu \mathrm{m}$ at a feed rate of $3 \mu \mathrm{m} /$ tooth with $0^{\circ}$ orientation to $103.5 \mu \mathrm{m}$ at feed rate $6 \mu \mathrm{m} /$ tooth with $0^{\circ}$ orientation.

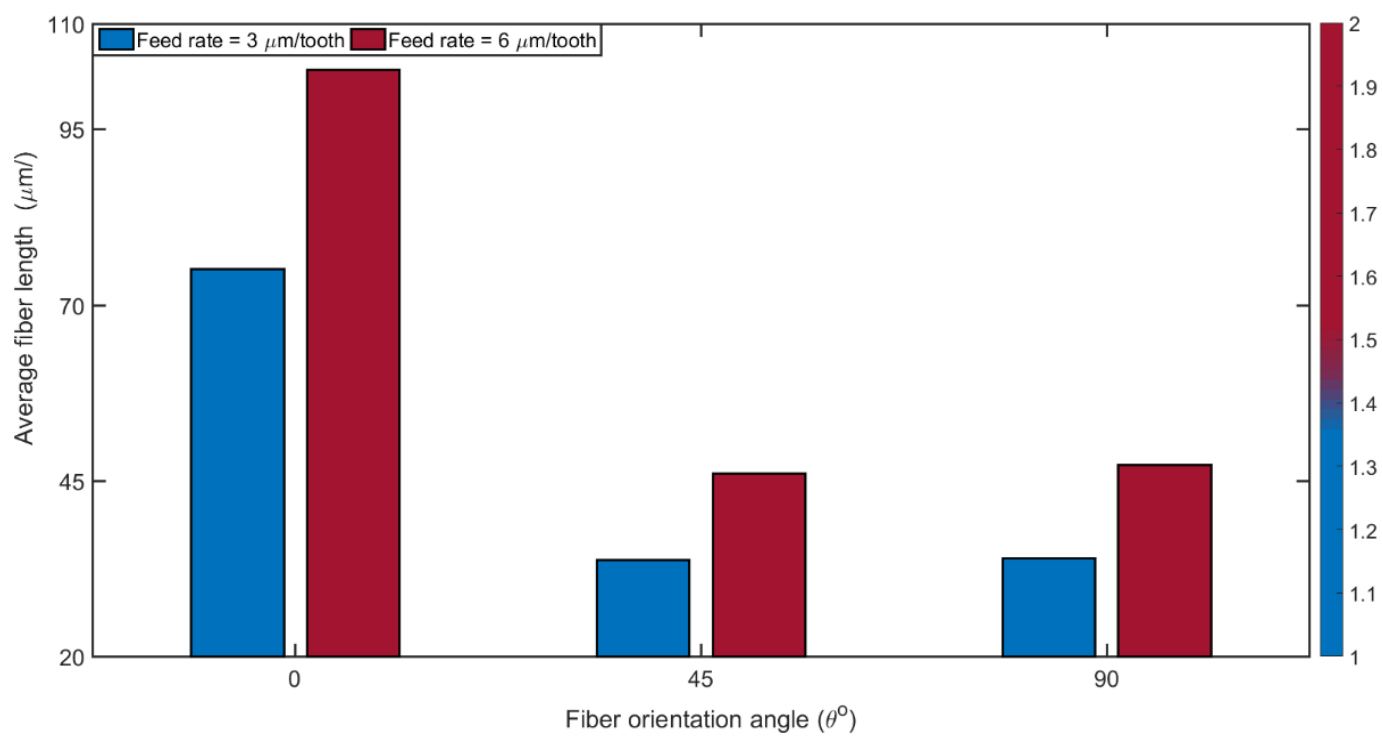

Figure 13. Average fiber length measurements of $0^{\circ}, 45^{\circ}$, and $90^{\circ}$ fiber orientations at feed rates 3 and $6 \mu \mathrm{m} /$ tooth and dry milling condition (at 20,000 rpm speed).

\subsection{Impact of Fiber Orientation on CFRP Surface Finish}

When CFRPs are subjected to milling, the formed surface is irregular because of the pulling and separation of the fibers from the matrix [69]. The irregular surface is also the result of variation in cutting forces when the tool cuts the fibers and then the matrix. It has been reported previously that surface damage when milling CFRP occurs in the transition zone [70-72].

Figure 14 illustrates the surface damage of unidirectional CFRP laminate at $0^{\circ}, 45^{\circ}$, and $90^{\circ}$ TFOAs. The TFOA appears to be the dominant factor for the surface generated (Figure 14) as the surfaces for the $45^{\circ}$ and $90^{\circ}$ orientations are more severely damaged than that for $0^{\circ}$ orientation. In fact, at $0^{\circ}$ TFOA, the cutting orientation is parallel to the fibers orientation and the major chip formation mechanism is delamination, so there is minimum interaction between fibers and cutting edge. For the $90^{\circ} \mathrm{TFOA}$, the cutting orientation is orthogonal to the fibers, causing the greater interaction between fibers and the cutting edge. For $45^{\circ}$, the fibers are both dragged and sheared. This behavior is well known in the literature $[73,74]$. In the case of fibers oriented at $45^{\circ}$ and $90^{\circ}$, the fibers were not completely removed because of the large bending deformation taking place. It can be thus concluded that during machining of CFRP, surface damage is related to the chip formation mechanism where bending and shearing of fibers dominate the mechanism [60]. 

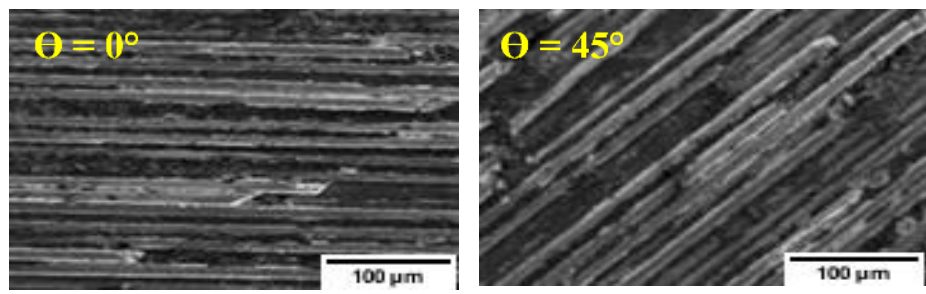

(a)
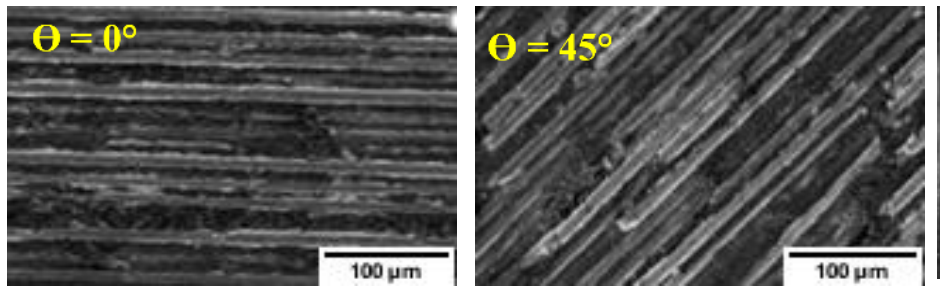

(b)
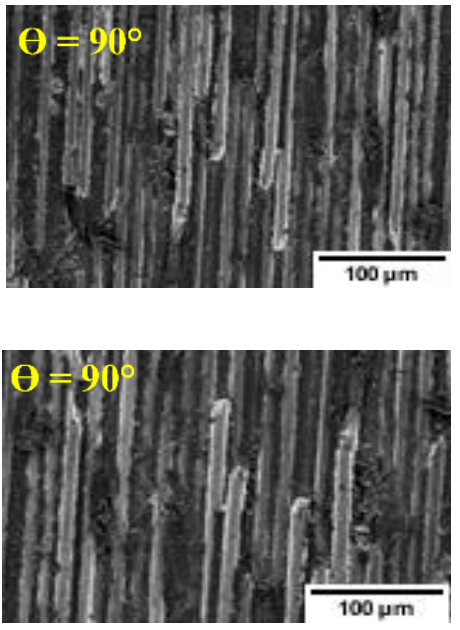

Figure 14. SEM images of a machined surface obtained after milling $0^{\circ}, 45^{\circ}$, and $90^{\circ} \mathrm{TFOA}$ (feed rate $\mu \mathrm{m} /$ tooth and speed of 20,000 rpm): (a) ACF vegetable oil conditions and (b) dry.

Moreover, the TFOA seriously affects the tool cutting-edge wear, as a result of surface damage occurring within the workpiece during machining. The analysis of tool edge radius was described in Section 3.3. The results confirm the high effect of fiber orientations on tool wear. At $0^{\circ}$ fiber orientation, the surface integrity is much better than at $45^{\circ}$ or $90^{\circ}$ TFOA. In fact, at $0^{\circ}$, crushing and then fracture of fibers is dominant and therefore fibers crack or fracture at the cut surface. Instead, for other TFOAs (between $45^{\circ}$ and $90^{\circ}$ ), fracture occurs ahead of the tool, leading to further damage of the surface as a result of the uncontrolled action of the broken fibers.

Nevertheless, it should be noted that employing ACF vegetable oil did not show a pronounced effect on the machined surface when compared to dry milling. The use of ACF vegetable oil, however, as a spray in the cutting zone, is a viable lubricating method for CFRP since the spray will evaporate and will not be absorbed by the workpiece. Thus, the structural integrity of the CFRP will not be damaged because of moisture from the lubricant. This is in agreement with our earlier findings [48,49].

\section{Conclusions}

The milling performance of CFRPs when using atomized vegetable oil as a lubricant was investigated in this research work as a function of fiber orientations and cutting feed rate. The process performance indicators studied were the cutting force, the tool wear, delamination, and surface texture. The results obtained from this study led to the following conclusions:

(1) When machining CFRPs, the cutting direction, in relation to the fiber orientation, strongly influences chip formation, on which depends resistance to cutting, cutting force, fiber breakage, tool wear, the quality of the machined surface and the delamination. These indicators depend on the machining parameters used and on the cutting conditions.

(2) The delamination percentage when cutting at TFOAs of $0^{\circ}, 30^{\circ} 45^{\circ}, 60^{\circ}$, and $90^{\circ}$ were improved by $65 \%, 91 \%, 54 \%, 66 \%$, and $75 \%$, respectively, under ACF (vegetable oil) conditions at $3 \mu \mathrm{m} /$ tooth. Machining with $45^{\circ}$ TFOA produces maximum damage at high feed rate.

(3) As expected, increase in feed rate increased the cutting force because of high chip load, especially in cutting directions where the fiber strength is high and with dry machining. Using a lubricant decreased the friction between the chip and the rake face of the tool, reduced the abrasive effect of broken fibers, and thus lowered cutting force and tool wear. 
(4) The magnitude of resultant cutting force was found to be greater in the dry condition relative to the ACF condition by about $23 \%, 31 \%, 26 \%, 25 \%$, and $23 \%$, respectively, for the samples in the $0^{\circ}, 30,45^{\circ}, 60^{\circ}$, and $90^{\circ}$ TFOA at $6 \mu \mathrm{m} /$ tooth of feed rate. However, the use of atomized vegetable oil mixed with water improved the process performance compared to dry machining in that it reduced the cutting force, the delamination percentage and the tool edge rounding.

(5) The tool damage was examined and measured using a 3D optical microscope (Olympus BXFM). $90^{\circ}$ TFOA produced a large amount of tool edge rounding. Contrastingly, $0^{\circ}$ TFOA has the least amount of edge rounding. However, the lowest values of edge radius evolution as a measure of the tool wear were $12 \mu \mathrm{m}$ and $16.5 \mu \mathrm{m}$ with TFOA from $0^{\circ}$ to $90^{\circ}$ at feed rate $3 \mu \mathrm{m} /$ tooth under ACF (vegetable oil) conditions.

(6) The findings of this study further support the use of the vegetable oil-in-water emulsion obtained through ultrasonic atomization as an effective and environmentally friendly lubricant for improving the machining of CFRPs.

Author Contributions: Conceptualization and Methodology (T.-S.-M.E. and M.B.-G.J.), Experimental (T.-S.-M.E.), Formal analysis (T.-S.-M.E.), Writing-Original Draft (T.-S.-M.E.); Resources, supervision, writing-Review \& Editing (V.S. and M.B.-G.J.) and final revision and editing (A.M.S.). All authors have read and agreed to the published version of the manuscript.

Funding: This research was funded by the National Sciences and Engineering Research Council of Canada (NSERC) and the Technology Innovation Program (10053248, Development of Manufacturing System for CFRP).

Institutional Review Board Statement: Not applicable.

Informed Consent Statement: Not applicable.

Data Availability Statement: Not applicable.

Acknowledgments: The authors also wish to thank the Ministry of Higher Education and Scientific Research in Libya in collaboration with the Canadian Bureau for International Education (CBIE) for providing the Ph.D. scholarship of the first author (T.E.).

Conflicts of Interest: The authors declare no conflict of interest.

\section{Nomenclature}

\begin{tabular}{|c|c|c|c|}
\hline CFRP & carbon fiber reinforced polymer & rpm & revolution per minute \\
\hline $\mathrm{ACF}$ & atomization cutting fluid & $\varnothing$ & shear angle $\left({ }^{\circ}\right)$ \\
\hline TFOA & $\begin{array}{l}\text { Tool displacement direction-fiber } \\
\text { orientation angle: } \theta\left(^{\circ}\right)\end{array}$ & $\alpha$ & rake angle $\left(^{\circ}\right)$ \\
\hline$F x$ & normal force in the $x$ direction & $\beta$ & friction angle $\left(^{\circ}\right)$ \\
\hline$F y$ & feed force in the y direction & $\mathrm{N}$ & newton \\
\hline$F z$ & force in the $\mathrm{z}$ direction & $\mu \mathrm{m}$ & micrometer \\
\hline Fc & cutting force & $D p$ & delamination percentage $(\%)$ \\
\hline$F t$ & thrust force & $W_{\max }$ & maximum damage width (mm) \\
\hline$R$ & resultant cutting force & $W$ & original slot width (mm) \\
\hline
\end{tabular}

\section{References}

1. $\mathrm{Hu}, \mathrm{N}$.; Zhang, L. Some observations in grinding unidirectional carbon fibre-reinforced plastics. J. Mater. Process. Technol. 2004, 152, 333-338. [CrossRef]

2. Wang, C.; Liu, G.; An, Q.; Chen, M. Occurrence and formation mechanism of surface cavity defects during orthogonal milling of CFRP laminates. Compos. Part B Eng. 2017, 109, 10-22. [CrossRef]

3. Che, D.; Saxena, I.; Han, P.; Guo, P.; Ehmann, K.F. Machining of carbon fiber reinforced plastics/polymers: A literature review. J. Manuf. Sci. Eng. 2014, 136, 034001. [CrossRef]

4. Dandekar, C.R.; Shin, Y.C. Modeling of machining of composite materials: A review. Int. J. Mach. Tools Manuf. 2012, 57, 102-121. [CrossRef]

5. Bhatnagar, N.; Ramakrishnan, N.; Naik, N.; Komanduri, R. On the machining of fiber reinforced plastic (FRP) composite laminates. Int. J. Mach. Tools Manuf. 1995, 35, 701-716. [CrossRef] 
6. Rahman, M.; Ramakrishna, S.; Prakash, J.; Tan, D. Machinability study of carbon fiber reinforced composite. J. Mater. Process. Technol. 1999, 89, 292-297. [CrossRef]

7. Santhanakrishnan, G.; Krishnamurthy, R.; Malhotra, S. Machinability characteristics of fibre reinforced plastics composites. J. Mech. Work. Technol. 1988, 17, 195-204. [CrossRef]

8. Teti, R. Machining of composite materials. CIRP Ann. 2002, 51, 611-634. [CrossRef]

9. Chen, W.-C. Some experimental investigations in the drilling of carbon fiber-reinforced plastic (CFRP) composite laminates. Int. J. Mach. Tools Manuf. 1997, 37, 1097-1108. [CrossRef]

10. Ho-Cheng, H.; Dharan, C. Delamination during drilling in composite laminates. J. Manuf. Sci. Eng. 1990, 112, 236-239. [CrossRef]

11. Shen, Z.; Lu, L.; Sun, J.; Yang, F.; Tang, Y.; Xie, Y. Wear patterns and wear mechanisms of cutting tools used during the manufacturing of chopped carbon fiber. Int. J. Mach. Tools Manuf. 2015, 97, 1-10. [CrossRef]

12. Koenig, W.; Wulf, C.; Grass, P.; Willerscheid, H. Machining of fibre reinforced plastics. CIRP Ann. 1985, 34, 537-548. [CrossRef]

13. Xu, W.-X.; Zhang, L.-C. Ultrasonic vibration-assisted machining: Principle, design and application. Adv. Manuf. 2015, 3, 173-192. [CrossRef]

14. Ramulu, M.; Faridnia, M.; Garbini, J.; Jorgensen, J. Machining of graphite/epoxy composite materials with polycrystalline diamond (PCD) tools. J. Eng. Mater. Technol. 1991, 113, 430-436. [CrossRef]

15. Wang, D.; Ramulu, M.; Arola, D. Orthogonal cutting mechanisms of graphite/epoxy composite. Part I: Unidirectional laminate. Int. J. Mach. Tools Manuf. 1995, 35, 1623-1638. [CrossRef]

16. Wang, D.; Ramulu, M.; Arola, D. Orthogonal cutting mechanisms of graphite/epoxy composite. Part II: Multi-directional laminate. Int. J. Mach. Tools Manuf. 1995, 35, 1639-1648. [CrossRef]

17. Calzada, K.A.; Kapoor, S.G.; DeVor, R.E.; Samuel, J.; Srivastava, A.K. Modeling and interpretation of fiber orientation-based failure mechanisms in machining of carbon fiber-reinforced polymer composites. J. Manuf. Process. 2012, 14, 141-149. [CrossRef]

18. Geng, D.; Liu, Y.; Shao, Z.; Lu, Z.; Cai, J.; Li, X.; Jiang, X.; Zhang, D. Delamination formation, evaluation and suppression during drilling of composite laminates: A review. Compos. Struct. 2019, 216, 168-186. [CrossRef]

19. Pwu, H.; Hocheng, H. Chip formation model of cutting fiber-reinforced plastics perpendicular to fiber axis. J. Manuf. Sci. Eng. 1998, 120, 192-196. [CrossRef]

20. Turner, J.; Scaife, R.J.; El-Dessouky, H. Effect of machining coolant on integrity of CFRP composites. Adv. Manuf. Polym. Compos. Sci. 2015, 1, 54-60. [CrossRef]

21. Ghafarizadeh, S.; Lebrun, G.; Chatelain, J.-F. Experimental investigation of the cutting temperature and surface quality during milling of unidirectional carbon fiber reinforced plastic. J. Compos. Mater. 2016, 50, 1059-1071. [CrossRef]

22. Liu, J.; Chen, G.; Ji, C.; Qin, X.; Li, H.; Ren, C. An investigation of workpiece temperature variation of helical milling for carbon fiber reinforced plastics (CFRP). Int. J. Mach. Tools Manuf. 2014, 86, 89-103. [CrossRef]

23. Hocheng, H.; Puw, H.; Huang, Y. Preliminary study on milling of unidirectional carbon fibre-reinforced plastics. Compos. Manuf. 1993, 4, 103-108. [CrossRef]

24. Takeyama, H.; Iijima, N. Machinability of glassfiber reinforced plastics and application of ultrasonic machining. CIRP Ann. 1988, 37, 93-96. [CrossRef]

25. Wang, X.M.; Zhang, L. An experimental investigation into the orthogonal cutting of unidirectional fibre reinforced plastics. Int. J. Mach. Tools Manuf. 2003, 43, 1015-1022. [CrossRef]

26. Zhang, L.; Zhang, H.; Wang, X. A force prediction model for cutting unidirectional fibre-reinforced plastics. Mach. Sci. Technol. 2001, 5, 293-305. [CrossRef]

27. Lopez de Lacalle, N.; Lamikiz, A.; Campa, F.; Valdivielso, A.F.; Etxeberria, I. Design and test of a multitooth tool for CFRP milling. J. Compos. Mater. 2009, 43, 3275-3290. [CrossRef]

28. Sheikh-Ahmad, J.; Yadav, R. Model for predicting cutting forces in machining CFRP. Int. J. Mater. Prod. Technol. 2008, 32, $152-167$. [CrossRef]

29. Karpat, Y.; Bahtiyar, O.; Değer, B. Mechanistic force modeling for milling of unidirectional carbon fiber reinforced polymer laminates. Int. J. Mach. Tools Manuf. 2012, 56, 79-93. [CrossRef]

30. Shahrajabian, H.; Hadi, M.; Farahnakian, M. Experimental investigation of machining parameters on machinability of carbon fiber/epoxy composites. Int. J. Eng. Innov. Technol. 2012, 3, 30-36.

31. Caggiano, A.; Improta, I.; Nele, L. Characterization of a new dry drill-milling process of Carbon Fibre Reinforced Polymer laminates. Materials 2018, 11, 1470. [CrossRef] [PubMed]

32. Ismail, S.O.; Sarfraz, S.; Niamat, M.; Mia, M.; Gupta, M.K.; Pimenov, D.Y.; Shehab, E. Comprehensive study on tool wear during machining of fiber-reinforced polymeric composites. In Machining and Machinability of Fiber Reinforced Polymer Composites; Springer: Singapore, 2021; pp. 129-147.

33. Xia, T.; Kaynak, Y.; Arvin, C.; Jawahir, I. Cryogenic cooling-induced process performance and surface integrity in drilling CFRP composite material. Int. J. Adv. Manuf. Technol. 2016, 82, 605-616. [CrossRef]

34. Basmaci, G.; Yoruk, A.S.; Koklu, U.; Morkavuk, S. Impact of cryogenic condition and drill diameter on drilling performance of CFRP. Appl. Sci. 2017, 7, 667. [CrossRef]

35. Impero, F.; Dix, M.; Squillace, A.; Prisco, U.; Palumbo, B.; Tagliaferri, F. A comparison between wet and cryogenic drilling of CFRP/Ti stacks. Mater. Manuf. Process. 2018, 33, 1354-1360. [CrossRef] 
36. Iqbal, A.; Zhao, G.; Zaini, J.; Gupta, M.; Jamil, M.; He, N.; Nauman, M.; Mikolajczyk, T.; Pimenov, D. Between-the-holes cryogenic cooling of the tool in hole-making of Ti-6Al-4V and CFRP. Materials 2021, 14, 795. [CrossRef]

37. Joshi, S.; Rawat, K.; Balan, A. A novel approach to predict the delamination factor for dry and cryogenic drilling of CFRP. J. Mater. Process. Technol. 2018, 262, 521-531. [CrossRef]

38. Khairussaleh, N.K.M.; Haron, C.H.C.; Ghani, J.A. Study on wear mechanism of solid carbide cutting tool in milling CFRP. J. Mater. Res. 2016, 31, 1893. [CrossRef]

39. Khairusshima, M.N.; Hassan, C.C.; Jaharah, A.; Amin, A.; Idriss, A.M. Effect of chilled air on tool wear and workpiece quality during milling of carbon fibre-reinforced plastic. Wear 2013, 302, 1113-1123. [CrossRef]

40. Siniawski, M.T.; Saniei, N.; Adhikari, B.; Doezema, L.A. Influence of fatty acid composition on the tribological performance of two vegetable-based lubricants. J. Synth. Lubr. 2007, 24, 101-110. [CrossRef]

41. Zimmerman, J.B.; Clarens, A.F.; Hayes, K.F.; Skerlos, S.J. Design of hard water stable emulsifier systems for petroleum-and bio-based semi-synthetic metalworking fluids. Environ. Sci. Technol. 2003, 37, 5278-5288. [CrossRef]

42. Abdalla, H.; Baines, W.; McIntyre, G.; Slade, C. Development of novel sustainable neat-oil metal working fluids for stainless steel and titanium alloy machining. Part 1. Formulation development. Int. J. Adv. Manuf. Technol. 2007, 34, 21-33. [CrossRef]

43. Shashidhara, Y.; Jayaram, S. Vegetable oils as a potential cutting fluid-An evolution. Tribol. Int. 2010, 43, 1073-1081. [CrossRef]

44. Alves, S.M.; de Oliveira, J.F.G. Development of new cutting fluid for grinding process adjusting mechanical performance and environmental impact. J. Mater. Process. Technol. 2006, 179, 185-189. [CrossRef]

45. Gryglewicz, S.; Piechocki, W.; Gryglewicz, G. Preparation of polyol esters based on vegetable and animal fats. Bioresour. Technol. 2003, 87, 35-39. [CrossRef]

46. Kamogawa, K.; Akatsuka, H.; Matsumoto, M.; Yokoyama, S.; Sakai, T.; Sakai, H.; Abe, M. Surfactant-free O/W emulsion formation of oleic acid and its esters with ultrasonic dispersion. Colloids Surf. A Physicochem. Eng. Asp. 2001, 180, 41-53. [CrossRef]

47. Sakai, T. Surfactant-free emulsions. Curr. Opin. Colloid Interface Sci. 2008, 13, 228-235. [CrossRef]

48. Elgnemi, T.; Ahmadi, K.; Songmene, V.; Nam, J.; Jun, M.B. Effects of atomization-based cutting fluid sprays in milling of carbon fiber reinforced polymer composite. J. Manuf. Process. 2017, 30, 133-140. [CrossRef]

49. Jun, M.B.; Joshi, S.S.; DeVor, R.E.; Kapoor, S.G. An experimental evaluation of an atomization-based cutting fluid application system for micromachining. J. Manuf. Sci. Eng. 2008, 130, 031118. [CrossRef]

50. Burton, G.; Goo, C.-S.; Zhang, Y.; Jun, M.B. Use of vegetable oil in water emulsion achieved through ultrasonic atomization as cutting fluids in micro-milling. J. Manuf. Process. 2014, 16, 405-413. [CrossRef]

51. Rukosuyev, M.; Goo, C.S.; Jun, M.B. Understanding the effects of the system parameters of an ultrasonic cutting fluid application system for micro-machining. J. Manuf. Process. 2010, 12, 92-98. [CrossRef]

52. Maegawa, S.; Morikawa, Y.; Hayakawa, S.; Itoigawa, F.; Nakamura, T. Mechanism for changes in cutting forces for down-milling of unidirectional carbon fiber reinforced polymer laminates: Modeling and experimentation. Int. J. Mach. Tools Manuf. 2016, 100, 7-13. [CrossRef]

53. Sheikh-Ahmad, J.Y. Machining of Polymer Composites; Springer: New York, NY, USA, 2009; Volume 387355391.

54. Wang, X.; Zhang, L. Machining damage in unidirectional fibre-reinforced plastics. In Abrasive Technology: Current Development and Applications I; World Scientific Publishing Co Pte Ltd.: Singapore, 1999; pp. 429-436.

55. Liu, Y.; Deng, J.; Wu, F.; Duan, R.; Zhang, X.; Hou, Y. Wear resistance of carbide tools with textured flank-face in dry cutting of green alumina ceramics. Wear 2017, 372, 91-103. [CrossRef]

56. Zhao, X.; Li, Y. Tool Wear Pattern and Mechanics in High Speed Cutting Microwave Printed Circuit Board. Key Eng. Mater. 2010, 426, 515-519. [CrossRef]

57. Nguyen, D.; Abdullah, M.S.B.; Khawarizmi, R.; Kim, D.; Kwon, P. The effect of fiber orientation on tool wear in edge-trimming of carbon fiber reinforced plastics (CFRP) laminates. Wear 2020, 450, 203213. [CrossRef]

58. Shirazinia, M.; Moya, R.; Muñoz, F. Properties of laminated curves manufactured with steamed veneers from fast-growth tropical wood in Costa Rica. Madera Y Bosques 2011, 17, 85-101. [CrossRef]

59. Kumar, D.; Gururaja, S. Machining damage and surface integrity evaluation during milling of UD-CFRP laminates: Dry vs Cryogenic. Compos. Struct. 2020, 247, 112504. [CrossRef]

60. Xiao, J.; Gao, C.; Ke, Y. An analytical approach to cutting force prediction in milling of carbon fiber reinforced polymer laminates. Mach. Sci. Technol. 2018, 22, 1012-1028. [CrossRef]

61. Niknam, S.A.; Songmene, V. Analysis of friction and burr formation in slot milling. Procedia CIRP 2014, 17, 755-759. [CrossRef]

62. Faraz, A.; Biermann, D.; Weinert, K. Cutting edge rounding: An innovative tool wear criterion in drilling CFRP composite laminates. Int. J. Mach. Tools Manuf. 2009, 49, 1185-1196. [CrossRef]

63. Zitoune, R.; Krishnaraj, V.; Almabouacif, B.S.; Collombet, F.; Sima, M.; Jolin, A. Influence of machining parameters and new nano-coated tool on drilling performance of CFRP/Aluminium sandwich. Compos. Part. B Eng. 2012, 43, 1480-1488. [CrossRef]

64. Nguyen, D.; Voznyuk, V.; Bin Abdullah, M.S.; Kim, D.; Kwon, P.Y. Tool Wear of Superhard Ceramic Coated Tools in Drilling of CFRP/Ti Stacks. In Proceedings of the International Manufacturing Science and Engineering Conference, Erie, PA, USA, 10-14 June 2019; American Society of Mechanical Engineers: New York, NY, USA, 2019; p. V002T003A089.

65. Swan, S.; Bin Abdullah, M.S.; Kim, D.; Nguyen, D.; Kwon, P. Tool wear of advanced coated tools in drilling of CFRP. J. Manuf. Sci. Eng. 2018, 140, 111018-1. [CrossRef] 
66. Maegawa, S.; Morikawa, Y.; Hayakawa, S.; Itoigawa, F.; Nakamura, T. Effects of fiber orientation direction on tool-wear processes in down-milling of carbon fiber-reinforced plastic laminates. Int. J. Autom. Technol. 2015, 9, 356-364. [CrossRef]

67. Rawat, S.; Attia, H. Wear mechanisms and tool life management of WC-Co drills during dry high speed drilling of woven carbon fibre composites. Wear 2009, 267, 1022-1030. [CrossRef]

68. Ramulu, M.; Kim, D.; Choi, G. Frequency analysis and characterization in orthogonal cutting of glass fiber reinforced composites Compos. Part. A Appl. Sci. Manuf. 2003, 34, 949-962. [CrossRef]

69. Davim, J.P.; Mata, F. Optimisation of surface roughness on turning fibre-reinforced plastics (FRPs) with diamond cutting tools. Int. J. Adv. Manuf. Technol. 2005, 26, 319-323. [CrossRef]

70. Liu, G.; Chen, H.; Huang, Z.; Gao, F.; Chen, T. Surface quality of staggered PCD end mill in milling of carbon fiber reinforced plastics. Appl. Sci. 2017, 7, 199. [CrossRef]

71. Hintze, W.; Hartmann, D. Modeling of delamination during milling of unidirectional CFRP. Procedia Cirp 2013, 8, 444-449. [CrossRef]

72. Hintze, W.; Cordes, M.; Koerkel, G. Influence of weave structure on delamination when milling CFRP. J. Mater. Process. Technol. 2015, 216, 199-205. [CrossRef]

73. Chang, C.-S. Turning of glass-fiber reinforced plastics materials with chamfered main cutting edge carbide tools. J. Mater. Process. Technol. 2006, 180, 117-129. [CrossRef]

74. Pecat, O.; Rentsch, R.; Brinksmeier, E. Influence of milling process parameters on the surface integrity of CFRP. Procedia Cirp 2012, 1, 466-470. [CrossRef] 